\title{
Big increase in Spanish research funding
}

[MADRID] The Spanish government plans to increase spending on civilian research and development by between 8 and 10 per cent next year. The precise figure is uncertain due to its inclusion in a new budget line that also includes military research.

Partly as a result of the inclusion of military projects, such as the development of weapons systems, Spain's total spending on research and development will increase to almost 1 per cent of gross national product (GNP). The country's current research expenditure is among the lowest in Europe.

Recent calculations suggest that the figure fell from 0.91 per cent of GNP in 1991 to 0.76 per cent in 1996 , when the comparable figure for neighbouring France was about 2.35 per cent. The increased science funding is part of a broad budget package aimed at preparing Spain for entry into the new European monetary system, which comes into operation next year.

The centre-right government plans to increase total public spending by 4.3 per cent in 1999 over the current year, made possible by its prediction that continued strength in the economy will give a 4.8 per cent increase in revenue, despite cuts in income tax rates.
According to government officials, the aim of the extra spending on research and development is to promote competition between companies and stimulate innovation to banish the widely held view that other countries are better at inventing things.

Plans for research have been outlined within a four-year budget framework. Priorities for investment will include energy research, biotechnology, archaeology, waste removal, and biomedicine and human health. Another priority will be information technology, including improved infrastructure to aid the flow of scientific data.

An Office of Science and Technology will be set up to monitor research spending and report direct to the presidency. Overall, there will be a 9.3 per cent increase in health spending and a 6.5 per cent increase on education.

The extra spending on research and development includes money for developing a range of military technologies, including the production of aircraft, frigates and tanks for the Ministry of Defence, at a cost of US\$1.42 billion.

Although some scientists are critical that this spending is being included in the overall $\mathrm{R} \& \mathrm{D}$ budget, the move is strongly defended by government officials, who point out that measuring total research effort in this way is a widely accepted practice in other countries.

The extra money for research has been widely welcomed in the scientific community, which has long complained of insufficient funding. Miguel Quintanilla Avila, head of the intracellular signalling department of the Institute of Biomedical Investigations at the Higher Council of Scientific Research (CSIC), says "any state initiative that leads to an increase in public spending on $\mathrm{R} \& \mathrm{D}$ is always welcome".

Quintanilla Avila points out that basic research in Spain will continue to face structural problems, such as the difficulty of obtaining funding for research fellowships, and the high number of researchers on short-term contracts. But he backs the goal of increasing research and development spending to 1 per cent of GNP.

In last week's budget, the government also promises to increase spending on environmental protection by 17.9 per cent, to a total of US\$1.47 billion. Almost four-fifths will be used for water-related infrastructure. The rest will be used for nature conservation and other projects.

XavierBosch

\section{French scientist shrugs off winning his second Ig Nobel prize}

[воSTON] French biomedical researcher Jacques Benveniste is set to become the first person to win two 'Ig Nobel' prizes when this year's awards are announced at a ceremony due to take place at Harvard University tonight (8 October).

Benveniste won his first ' $I g$ ' - awarded annually by Marc Abrahams, editor of The Annals of Improbable Research, and a group of scientists - in 1991 for his work claiming to show that antibody solutions retain their biological effectiveness, even when diluted to the point where no trace of the antibody is detectable (E. Davenas et al. Nature 333, 816-818; 1988). The water, Benveniste argues, preserves a 'memory' of the substance after it is gone.

The second Ig Nobel prize will be awarded for an extension of this work. Benveniste now claims that a solution's biological activity can be digitally recorded, stored on a computer hard drive, sent over the Internet as an attached document and transferred to a different water sample at the receiving end (see www.digibio.com).

"We've demonstrated that you can transmit the biological effect by e-mail between Chicago and Paris," says Benveniste, who heads the Digital Biology Laboratory in Clamart, near Paris, which is financed by the private company DigiBio SA. "With this approach, you could transfer

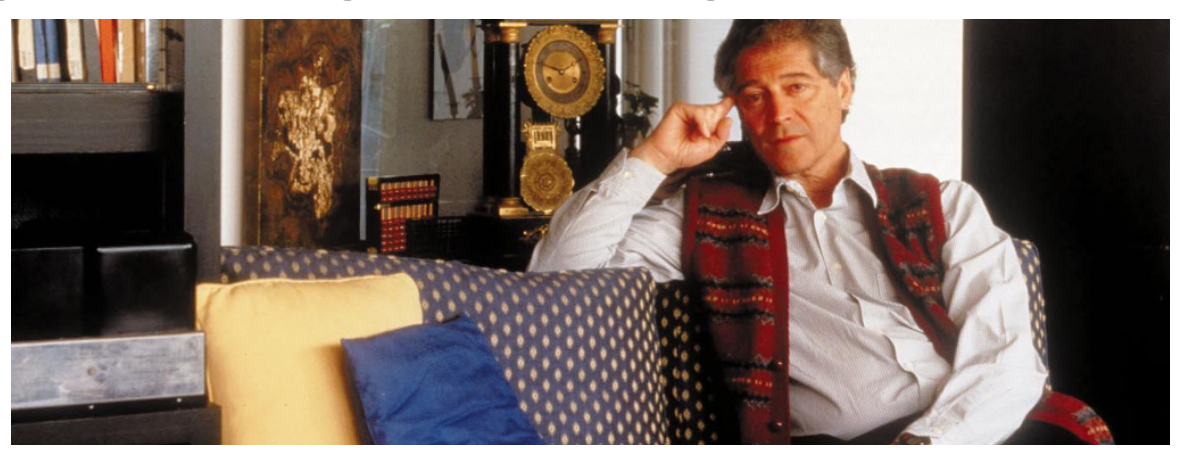

Unforgettable: Benveniste believes water has a memory and hopes to prove drug effects can be e-mailed.

the activity of a drug by means of standard telecommunications technology."

"French science has not risen to such giddy heights since $\mathrm{N}$-rays were invented by Blondlot early this century," says magician and sceptic James Randi, author of the forthcoming book A Magician in the Laboratory, based partly on his involvement in an investigation of Benveniste's laboratory practices carried out in 1988.

Benveniste argues that the science establishment is inherently resistant to new ideas. "Orthodox people are determined to block anything new in biology," he says.

He compares the conventional view that "you need a molecule to have a biological effect" to the debate between Descartes and Newton four centuries ago over whether action at a distance was possible. "I say the effect comes not from the molecule itself but from the signal it imparts."

Benveniste says he is "happy to receive a second Ig Nobel prize, because it shows that those making the awards don't understand anything. People don't give out Nobel prizes without first trying to find out what the recipients are doing. But the people who give out Ig Nobels don't even bother to inquire about the work."

Harvard chemist Dudley Herschbach, who won the 1986 Nobel Prize in Chemistry, finds Benveniste's claims "hard to reconcile with what we know about molecules". Herschbach considers the prize "very well deserved. And he just might win a third one if he keeps going in this way." Steve Nadis 